\title{
INTERCULTURAL COMPETENCE DEVELOPMENT IN COMENIUS PROJECT "ME AND MY EUROPE: INTERCULTURAL CHALLENGES OF MODERN PRE-PRIMARY EDUCATION" PARTICIPANTS AT PRE-PRIMARY EDUCATION
}

\author{
Anna Līduma \\ Riga Teacher Training and Educational Management Academy, Latvia
}

\begin{abstract}
The paper maximizes on the reflections on the Comenius project "Me and My Europe: Intercultural Challenges of Modern Pre-Primary Education" (implementation period 2012-2014) procedures in 9 states (Latvia, Lithuania, Estonia, Poland, Italy, Spain, Portugal, Island, Turkey). The Lifelong Learning Programme documents, Latvia Ministry of Education and Science documents on preschool education, preschool guidelines by CiCe and findings on competences by the scientist Spona are at the theoretical basis. The content describes the acquisition of the intercultural competences in team workshops and Art Labs. The project served as a tool to promote intercultural competences (knowledge, skills, attitudes and selfexperience) of the project participants (teachers, parents and young learners) and was attested by help of discussions, observations and a questionnaire.
\end{abstract}

Keywords: Comenius project, cooperation, intercultural competences.

\section{Introduction}

It is very important that pedagogy development was commenced with Great didactics by Czech pedagogue Jan Amos Comenius (1592-1670), who is considered the father of modern education throughout the world. His ideas are alive in contemporary Europe, due to the Lifelong learning project named after him, which is being implemented at all levels in accordance with the up to date technologies of the $21^{\text {st }}$ century. Intercultural experience is being fostered and the convergence (bringing closer) of miscellaneous nations is promoted thanks to Comenius projects.

"Comenius programme budget of nearly $€ 7$ billion, which ran from 20072013, funded a range of exchanges, study visits, and networking activities. The activities of LLP continue under the new Erasmus+ programme from 20142020” (Lifelong Learning Programme, 2014).

In the theoretical basis of this paper are: The documents of Lifelong Learning Programme (LLP), Latvia Ministry of Education and Science documents on preschool pedagogical process and citizenship promotion guidelines by $\mathrm{CiCe}$.

Over the course of its lifespan, LLP has provided support to school pupils, university students, adult learners, namely, to a variety of projects under four main sub-programmes: 1) Comenius for schools; 2) Erasmus for higher 
education; 3) Leonardo da Vinci for vocational education and training and 4) Grundtvig for adult education (About Lifelong Learning programme).

Comenius programme focuses on the first phase of education, from preschool and primary to secondary schools. It is relevant for all members of the education community: pupils, teachers, public authorities, parents' associations, non-government organizations, teacher training institutions, universities and all other educational staff. Comenius has the following goals:

"To improve and increase the mobility of pupils and educational staff in different Member States. To enhance and increase partnerships between schools in different Member States, with at least three million pupils taking part in joint educational activities by 2010. To encourage language learning, innovative ICT-based content, services and better teaching techniques and practices. To enhance the quality and European dimension of teacher training. To improve pedagogical approaches and school management" (Comenius Programme; Liduma, 2014:280-281).

The use of all possible methods, including information and communication technologies, for the production and dissemination of training materials to the widest possible audience is encouraged (Comenius Multilateral projects).

The documents of Latvia Education and Science Ministry define that the aim of the pre-school education programme is to promote the development of human and responsible individual personality, to encourage the formation of inquisitiveness towards individuals, environment and society and its diversity and unity. The objective of the pre-school education is to foster general development of children and their readiness to enter primary stage of the basic education (The education system in Latvia; Pre-school education ISCED level 0; Liduma, 2014).

In the Guidelines for Preschool teachers our CiCe colleagues recommend to discuss all topics with preschool children: "Early childhood institutions that exercise a democratic pedagogy give children the sense that everybody is part of society, and that they are valued and have a say" (Dyrfjord et al, 2004:4; Liduma, 2014:281).

As the theoretical basis of the project serves A. Spona's (A. Špona) theory on competences as a synergy formed by knowledge, skills, attitudes and selfexperience (Špona, 2006; Špona, Čamane, 2009).

This research gives characteristics of the development of the project participants' knowledge on the culture of the countries involved, skills to learn and use new information technologies, to start-up individual cooperation with individuals and to cooperate within groups, attitudes to their own country, as well as to people belonging to other countries and cultures and enrichment of self-experience due to completion of the tasks included into the project.

The aim of the research: To reveal Comenius project's significance in the Preschool education. 
The subject of the research: Intercultural competences of the project's participants.

Methods of the research are: theoretical methods and empirical methods: observations, and a questionnaire.

\section{Comenius project in practice}

The compulsory education primary school 'Ridze' gained the right to organize the Comenius project of Multilateral School partnership "Me and My Europe: Intercultural Challenges of Modern Pre-primary Education" from August 1, 2012 till July 31, 2014 and they involved into the project eight other countries as well.

The objectives of the partnership were as follows:

"Upgrading of the development necessity in children's intercultural competences within the pre-primary education among teachers; promoting the use of the national traditional culture in its diverse expressions as effective means for developing children's social and intercultural competences within the pre-primary education; encouraging parental involvement in the pedagogical process and contributing to formation of families' intercultural competences; developing and collecting innovative pedagogical approaches and methods, making use of ICT within pre-primary education; promoting dissemination of the best intercultural pedagogical practices among pre-primary educators at local and international level" (Project documents, 2012-2014).

The work was organized through two laboratories at each meeting in order to implement the above-mentioned objectives of the partnership project, during the Comenius project 'Me and my Europe' (2012-2014) (see Table 1).

Table 1. Comenius project Art Labs and Intercultural workshops

\begin{tabular}{|l|l|l|l|l|l|l|}
\hline Country & Latvia & Estonia & Iceland & Portugal & Turkey & Spain \\
\hline Art Lab & $\begin{array}{l}\text { My } \\
\text { country }\end{array}$ & Winter & The Sea & $\begin{array}{l}\text { Recycling } \\
\text { materials }\end{array}$ & Flowers & $\begin{array}{l}\text { My } \\
\text { national } \\
\text { meal }\end{array}$ \\
\hline $\begin{array}{l}\text { Inter- } \\
\text { cultural } \\
\text { workshop }\end{array}$ & $\begin{array}{l}\text { My folk } \\
\text { songs }\end{array}$ & $\begin{array}{l}\text { My folk } \\
\text { games }\end{array}$ & $\begin{array}{l}\text { My } \\
\text { national } \\
\text { outdoor } \\
\text { games }\end{array}$ & $\begin{array}{l}\text { My folk } \\
\text { music and } \\
\text { musical } \\
\text { instruments }\end{array}$ & $\begin{array}{l}\text { My national } \\
\text { fairy tales } \\
\text { (drama, } \\
\text { theatre) }\end{array}$ & $\begin{array}{l}\text { My folk } \\
\text { dances }\end{array}$ \\
\hline
\end{tabular}

In the framework of the project 7 meetings were organized: in Riga, Latvia; in Keila, Estonia; in Akranes, Iceland; in Sintra, Portugal; in Istanbul, Turkey; in LaGrange, Spain; in Grosseto and Paganico, Italy.

The first meeting of the project was organized in Latvia (26.09.2012.29.09.2012.). Participants were briefly introduced in the history of Latvia:

"Latvia (area: $64589 \mathrm{~km}^{2}$ ) is one of the Baltic States, a country in Northern Europe, on the Baltic Sea shore, bordering with Estonia in the North and 
Lithuania in the South, Russia and Belarus in the East. The capital city is Riga. Latvia is split into four parts called Kurzeme, Vidzeme, Zemgale, and Latgale. The population of Latvia from 2067887 people in 2011 during three years has decreased to 1997500 in 2014 (Iedzìvotāju skaits Latvijā noslìdējis zem diviem miljoniem, 2014). Latvian is the official language in the Republic of Latvia, spoken natively by approximately $63 \%$ of the residents of Latvia, approximately 1250000 people" (Latvian phrasebook, 2014).

"Latvia was settled by the Baltic tribes thousands of years ago. German traders and crusaders came to Latvia at the end of the 12th century. Over the next 800 years, Germans, Danes, Swedes, Poles, and Russians all invaded Latvia. Latvia finally gained its independence in 1918. The Soviet Union invaded Latvia during World War II and occupied Latvia until 1991, when the Soviet Union fell apart and Latvia regained its independence again. On 1 May 2004 Latvia became a member of the EU. Latvia has been a NATO member since 29 March, 2004,, (Latvia).

At the $1^{\text {st }}$ meeting of the project we explained the characteristics of learning possibilities in Primary school Ridze. (see Table 2)

Table 2. Learning possibilities in Primary school Ridze

\begin{tabular}{|l|l|l|l|}
\hline Education & Level & Students & Staff \\
\hline Basic Education & Grades: 1-9 & $\begin{array}{l}536 \\
\text { children }\end{array}$ & $\begin{array}{l}90 \\
\text { teachers }\end{array}$ \\
\cline { 1 - 2 } $\begin{array}{l}\text { Preschool groups } \\
\text { interests }\end{array}$ & $\begin{array}{l}\text { 5-7) music school; 2) art's centre; } \\
\text { 3) artistic creativity centre; 4) sport's } \\
\text { centre. }\end{array}$ & $\begin{array}{l}1500 \\
\text { pupils }\end{array}$ & \\
\hline
\end{tabular}

The content of the preschool program includes 12 subjects. There are 18 lessons per week: 3 or 4 lessons a day from Monday till Friday.

The primary school 'Rīdze' is the venue of different events, which are essential for development of learners through school traditions. In autumn School trip days and a Sports' day, a Poetry afternoon and Teachers' day are common.

Early primary school (Forms 1-4) pupils celebrate Miķeļa day (Michaelmas), organize Autumn goods market, and celebrate Mārtinus (Martin's day). Each year on Independence Day (the Republic of Latvia's anniversary commemoration day) we have a common a Festive morning, and a Military training parade is organized on Lāčplēša Day.

There is a tradition to organize celebrations of Christmas tree parties in each class together with the pupils' parents.

In spring we join together to enjoy the parents' thematic evening, a concert for grandparents "Ome/Opis", Mother's matinee, spring school trip day and the annual gala concert at the close of the school year. The project "The family 
enters the school", when the parents conduct lessons for the early primary school pupils (Forms 1-4), has been organized.

There are several competitions organized in the school: Stage Speech contest "Zvirbulis" (Sparrow) involving pupils of Forms 1-7, a contest "Cïrulitis" for young singers learning in Forms 1-4. The pupils of Form 9 take part in the competition "Kas notiek Latvijā?" (What's going on in Latvia?) organized by the newspaper 'Diena' (Pamatskola 'Rìdze', 2012).

During the first meeting of the project participants, the action plan was discussed and the further course of the project was made consistent there. The participants of the Comenius project gained experience of kindergarten work procedure at the preschool education institution 'Laismina' in Riga, Latvia, where the Michaelmas festival was celebrated. They could taste honey with Latvian rye bread and herbal tea there. The folk music laboratory involved the participants in learning of two folk songs "Lācīts kāpa ozolā" (Little bear climbed up the oak tree) and "Ko mēs labu stādīsim" (What shall we plant now) in Latvian.

At the social programme in Latvia, a folk instrument ensemble showed the art of playing "kokle", the Latvian national music instrument, introduced with folk traditional songs and dances, involved into active dancing all Comenius project participants. At the Riga meeting the Comenius participants were provided with the information on Riga and introduced with the posh Jugendstil, Art Nouveau architecture on Alberta Street and the pearl of the World Culture heritage - Old Riga. Due to the Michaelmas festival celebration in Riga (26.09.2012.-29.09.2012.), the Comenius project participants gained for themselves significant information on holidays and folk customs in Latvia.

Between Riga and Estonia meetings we organized an exhibition of Christmas cards in each partner institution and the Christmas cards were made and sent to all partners.

For the Estonian Art laboratory in city Keila (06.02.2013.-09.02.2013.) were prepared presentations about Winter. Latvians presented Winter birds. All preschool teachers and the children, whose parents supported the Comenius project, were involved into the work process. We also prepared two play-songs: "Kas dārzā" (Who is in the garden) and "Liela skāde" (Great damage). As Keila is situated in our close neighbourhood, all the preschool teachers went to enhance their experience to Estonia by bus. All the teams worked out a logo variant for the Comenius project in the meantime to the meeting in Estonia. The most successful was the concise logo made in Iceland.

In Estonia we learned about the practice in the private preschool and the practice in the state kindergarten as well as about the practice in two Estonian schools. The folk national culture programme was also provided and the socialising of project participants was encouraged. In Estonia the reflection on the accomplished and the programme for the meeting in Island was further 
refined. Another tradition started in Latvia was continued, so we were introduced with Old Tallinn.

Late May (28.05.2013.-02.06.2013.) brought us to Island. We felt the Nordic nature ourselves, found out the scarce flora and saw geysers and endured rain and the sharp solar wind.

At the Art laboratory were prepared presentations about the Sea. The Latvian team had prepared an integrated activity session presentation about the Sea, and the participants worked using the nature materials found gathered by preschool children nearby the Baltic beach.

The second laboratory provided learning of two sports games in open air. As the weather conditions were not benevolent, as it was raining hard, this laboratory took place indoors. We joined in the games named "Battle of snakes" and "Ball fight". These games develop children's ingenuity, flexibility, agility and reaction.

At the social programme Icelandic colleagues also showed the pupils' guitar playing art, and skills at both - the folk dance and the ballroom dance. The preschool age children also sang some songs. We observed how selfdependence was fostered in the kindergarten and the pupils' self-dependence and responsibility were encouraged at school. Iceland's specifics are parent coownership of their child (beginning from the preschool and throughout the school graduation). The parents are responsible for the pupils' performance at the school, not the teachers. The breaks at the school are meant for the teachers' recreation and preparation of materials for the next work session. The senior pupils take care of the junior pupils. So the social skills are developed (Liduma, 2014:283).

The next meeting's venue was in Sintra, Portugal (17.09.2013.22.09.2013.).

It has to be admitted that the Latvian Art laboratory, introducing with activities with buttons and straw sticks, was a success. All possible charms: bracelets, beads, rings, hair ornaments were made of them.

In the folk music workshop organized in Portugal the colleagues were introduced with music instruments of other countries. The most popular were the castanets, recycled materials were used to make them, too. (Walnut shells were used in different ways, round balls). Latvia showed the 'kokle' and the percussion instruments, likewise also Lithuania.

After the meeting in Portugal every country prepared a virtual exhibition "Me and my country". The pictures made by families were collected and presented on the project website. A short video with Christmas greetings of the children was created in every partner institution. A collection of videos 'Merry Christmas, Europe!' was made. The videos or the Internet links were sent to all partners.

The meeting in Turkey Istanbul (17.02.2014.-24.02.2014.) was a great success. At the Art laboratory artificial flowers were made from diverse 
materials. Dominant materials were paper, napkins and plastics. Latvia showed flower making by felting technique.

The other workshop was drama of folk fairy tales and legends. Latvia presented a fairy tale in Sand theatre technique.

The social programme was versatile: dervish dance art presentation, an art workshop visit. There were shared meals and a farewell party on the preschool premises. Sightseeing tours introduced us to Istanbul mosques, market diversity. Comenius participants found out the operation process of three kindergartens and two independent schools.

In Spain LaGrange (25.03.2014. -30.03.3014.) the meeting turned out as a major event for the local community, too. The Comenius project was reflected in the press. The LaGrange (Logroño) city education authorities handed out the certificates. The Spanish colleagues mainly introduced us with their country's customs and work at schools, dance art, and stands prepared at the school. On this occasion each team had prepared one recipe and demonstrated the cooking process at the kitchen in practice. At the Art laboratory, every team taught the others a popular dance of their country. Latvians introduced to their national folk dance "Tūdalin, tagadin," (Immediately, now).

During the social programme we went sightseeing around Logroño Old town, ancient village architecture, vine preparation processing and ancient dances, danced by men on wooden legs attached, were observed, but on our way home we were excited by the magnificent Art Nouveau at Bilbao, the capital of the Basque Country. Bilbao was associated with Barcelona in miniature, it was a wonderful oasis surrounded by mountains and protected from winds.

In Italy (12.05.2014.-18.05.2014.) the final gala meeting took place. Children and teachers of two kindergartens from Grosseto and Paganico presented Education System of Italy, peculiarities of preschool education and different social activities.

There was summarized everything achieved and gained during the Comenius project. The Italian colleagues introduced us with the Medieval architecture and ancient customs of folk songs of their country: such occasions bring together the whole Italian community: children, teachers, parents, educational authorities and the city administration as well. At the final gala event we enjoyed the gorgeous sound of the teachers' vocal ensemble of traditional and popular songs. The social programme was shaped so that the Comenius project participants could learn about nature, everyday life, ancient architecture and culture in general.

In particular, each team had its own definite duty at this project. The Polish team worked out the book about the whole project procedure - My European book. The Lithuanian team developed the website of the project. The countries presented their accomplishments in Italy. 


\section{Outcomes of the Comenius project}

The organizers of the project - the Latvia's team summarized the project's results. In total 1334 respondents participated in the project: namely, 128 preschool teachers and 1206 preschool pupils. At the workshops and art labs the representatives of each country showed appropriate samples for preschool age children, which fostered the children's intercultural competences.

The project evaluation was carried out as a step-by step process during the entire period of the project.

From the discussions with the partners of the project we could conclude that every participant of the project: the children, the teachers, the parents, gained much. Their self-experience was enriched on culture, education of all the participating countries. The children learned folksongs, folkdances, drama, playing of the folk instrument of other nations. As the preparation time period for each project meeting was limited and tense, the children at the author's music sessions were involved in simultaneous activities: they sang songs and coloured the participating countries' flags, coats of arms and the names of the countries, as well as welcome greetings' flowers for the participants arriving from other countries.

The parents of the Latvia's children widely supported our participation in the project: both by going together with their children to gather nature materials in Jurmala and by giving their photos to be included in the presentation "Me and My country". Everyone felt greatly rewarded due to his or her activities.

The children painted and coloured with great passion, sang, danced, made greeting cards and posters, Christmas seasonal greetings, learned how to greet and welcome the Comenius project participants in their languages and in the English language. positive.

Evaluation of the project meetings was done and the answers were mostly

About the atmosphere during meetings: "The atmosphere during the meetings was really nice and aesthetic. Everyone was very friendly. But our English could be better. The working atmosphere was good but it felt like that we had too little time for doing the work. I thought that there should have been more time for our lab, instead there was more time spent in Spanish lab."

The answers to the $2^{\text {nd }}$ question: "Were you satisfied with presentations of partners for the art lab?' were positive: "Each partner prepared the presentation and materials very well to the art lab. We shared new and interesting ideas for use in our work. Partners showed the culture of folk of different countries. The Art Labs were varied and very enriching."

Partners' answers to the $3^{\text {rd }}$ question: "Were you satisfied with presentations for the intercultural teachers' workshop?" were: "The Workshop about "My National Outdoor Games" was great fun, and provided us with lots of ideas how to play intercultural games with our pupils at school. The 
Workshop about "My Folk Music and Musical Instruments" was very interesting. Partners showed different presentations and videos to explain these issues, and even took some traditional instruments there. Folk fairy tales during workshop showed the differences between nations. In Italy the partners presented Comenius day, photos from the meeting and Project website."

Some answers to the $4^{\text {th }}$ question about the time for discussions were: Yes, our coordinator made a list of questions about issues. This was very helpful and we had enough time to discuss it. We had a good coordination meeting, it gave us time to discuss important things".

Answers to the $5^{\text {th }}$ question about the social programme were as follows: There was a warm welcome in the kindergarten and the tour with guide gave a good insight into Riga city. We enjoyed the folk music ensemble and had dinner in a traditional restaurant. Getting to know other cultures is very important in this project, so that we can transmit them in our schools. The Estonian team made a great effort: they showed us different schools and kindergartens; we visited Tallinn, watched and enjoyed typical dances. The Icelandic team showed us amazing places and schools. Portugal partners showed a lot of historic places and the Atlantic Ocean. The Turkish team also made a great effort: we visited different schools; we learnt a lot about Istanbul and got to know their amazing culture. Yes, we were able to see different kind of places and also we had to taste Spanish culture. Yes, there was a great hospitality and we had a wonderful sightseeing and taste of Italian food."

In general the partners were satisfied with accommodation and meeting rooms.

Critical remarks were addressed to rather weak Internet connections in partner countries and some difficulties were with planning and communication.

Afterwards the techniques learned during the Art Lab were disseminated and included into the pedagogical process of each preschool by participant country. Each country tried to create something original. Especially, various techniques of creating floral arrangements (Turkey) and Art Lab (Portugal) promoting use of recyclable materials should be mentioned.

The discussions' results with the teachers, parents and children in Latvia showed that the Comenius Project helped to improve intercultural competences and communication skills.

The impact of the project on children: certain improvement in knowledge of the cultures of partner countries: flags, songs, habits, names of country; learning of some words and catchphrases: please, thank you, how are you; higher level of self-experience and creative self-expression in singing, dancing and theatre.

The impact of the Project on teachers: improvement of language using skills. Better knowledge of the partner countries culture, habits; awareness of the own identity in the local, national and European level; self-experience at using IT resources. 
The impact of the Project onto parents: satisfaction with the possibility to include pictures in presentation "Me and My country" and with the new experience of children (participation in art labs, singing folk songs); improvement of the self-experience to cooperate with their own children.

\section{Conclusions}

The partnership included a wide geographic range (LV, ES, IT, EE, IS, PL, TR, PT, LT) and united partners representing the preschool educational systems with very different social contexts and traditions.

During the project participants improved their intercultural experience and competences: in acquiring of the Native Country (understanding the Homeland's treasures); in cooperation with the children and parents (involvement in the process of the Project); improvement of the abilities to use different techniques (You Tube; films; Video; presentations, information about the country); improvement of language skills. Creative realization of the additional tasks, preparation of two important booklets: Education system of the country; Recipes.

The outcomes of the project allowed to conclude that the Comenius project of Multilateral School partnership "Me and My Europe: Intercultural Challenges of Modern Pre-primary Education" served as a means to learn about culture treasures in the partner countries, to explore their own country, to improve intercultural competences and cooperation between the Teacher and the Student within the school pedagogical process.

\section{References}

About Lifelong Learning programme.

Available at: http://eacea.ec.europa.eu/llp/about_llp/about_llp_en.php

Comenius Programme.

Available at: http://eacea.ec.europa.eu/llp/comenius/comenius_en.php

Dyrfjord, K., Fumat, Y., Kusner, M., Anderson, R. (2004) Professional Guidance: Citizenship Education and Identity in courses for those who will work with Pre-School Children. Ed. By A. Ross. London: London Metropolitan University.

Iedzīvotāju skaits Latvijā noslīdējis zem diviem miljoniem, 2014. Available at: http://www.tvnet.lv/zinas/latvija/513377

iedzivotaju_skaits_latvija_noslidejis_zem_diviem_miljoniem

Liduma, A. (2014). Citizenship promotion opportunities: reflections on the Comenius Project 'Me and My Europe: Intercultural Challenges of Modern Pre-primary Education'. In P. Cunningham \& N. Fretwell (eds.) Innovative Practice and Research Trends in Identity, Citizenship and Education: Selected papers from the 16th Conference of the CICE Academic Network, London: CiCe, pp. 280-285.

About Comenius. Available at: http://www.britishcouncil.org/comenius-about-us.htm

Comenius Multilateral projects. Available at: http://eacea.ec.europa.eu/llp/comenius/ comenius_multilateral_projects_en.php

Latvia. Available at: http://simple.wikipedia.org/wiki/Latvia

Latvian phrasebook, 2014. Available at: http://wikitravel.org/en/Latvian_phrasebook 
Lifelong Learning Programme. Available at: http://ec.europa.eu/education/ tools/llp_en.htm Pamatskola 'Rìdze', 2012. Available at: http://www.ridze.lv/

Pre-school education. Available at: http://izm.izm.gov.lv/education/general-education/ preschool.html

The education system in Latvia. Pre-school education (ISCED level 0). Available at: http://izm.izm.gov.lv/education/education-system.html?print=1

Project documents 2012-2014. Me and My Europe: Intercultural Challenges of Modern PrePrimary Education. Available at: http://www.meandmyeurope.eu/

Špona, A. (2006). Audzināšanas process teorijā un praksē. Rīga: Raka.

Špona, A., Čamane, I. (2009). Audzināšana Pašaudzināšana. Rīga: Raka. 